AGRO EKONOMI, Vol 30, Issue 1, June 2019, Page.41-52

DOI : http://doi.org/10.22146/ae.44856

ISSN 0215-8787 (print), ISSN 2541-1616 (online) Available at https://jurnal.ugm.ac.id/jae/

\title{
THE EXPORT DETERMINANTS OF INDONESIAN CUT FLOWER IN THE INTERNATIONAL MARKET
}

\author{
Niza Arumta ${ }^{1}$, Jangkung Handoyo Mulyo $^{2}$, Irham $^{3}$ \\ 1,2,3 Department of Agricultural Socio Economics, Faculty of Agriculture, \\ Universitas Gadjah Mada \\ Jl. Flora, Bulaksumur, Kec.Depok, Kabupaten Sleman, \\ Daerah Istimewa Yogyakarta 55281 \\ nizaarumtamumtaza@gmail.com
}

Submitted : 22 April 2019; Revised : 8 May 2019; Accepted : 8 July 2019

\begin{abstract}
Trade statistics of Indonesian cut flower indicates the potential of Indonesia as an exporting country. The international market becomes more attractive as the increasing trend of demand and the rising cost for producing cut flowers show the various challenges for emerging countries. This study investigates whether the analytical gravity model fixed effect, common effect or random effect model is proper and what determinants having significant effects to the exports of Indonesian cut flower to partner countries. The data encompasses the period of 2008 to 2017 as the series data and the seven destination export countries from Indonesia as the cross-sectional data, using panel regression with the basic gravity model. The estimation results show that the fixed effects model is the proper model to explain the determinants of bilateral export on cut flower. The estimations imply the corroborate signs with GDP per capita of Indonesia, GDP per capita of partner countries and exchange rate, while those variables with the opposite sign are distance and trade openness. Thus, the export promotion, quality improvement and technology development are required in the development of export of cut flower industries.
\end{abstract}

Keywords: cut flower; gravity model; international trade

Arumta, N., Mulyo, J.H., \& Irham. (2019) The Export Determinants of Indonesian Cut Flower in The International Market. Agro Ekonomi 30(1), 41-52

\section{INTRODUCTION}

Indonesian cut flower industry has been growing rapidly as a result of greater domestic floriculture consumption and the increases in cut flower exports within the past decade. Indonesia enjoys the excess export of cut flower in international trade. According to UN Comtrade, 2018, the total export value of Indonesian cut flower in 2008 -2017 was US\$ 90.64 million and the import value was US\$ 7.18 million. The development of export value of Indonesian cut flower over the past ten years has placed in the top 20 exporters of cut chrysanthemums and top 40 exporters of cut roses in the world. Interestingly, Indonesia has become an 
emerging important production base for the production of cut flower in the world. The climate conditions, genetic diversity, labor-intensive resources, and developing infrastructure have improved Indonesia's position in international trade. Focusing on specific commodities may develop the nation's comparative advantage. With this objective in mind, this study attempts to find out the determinant factors and the best model to portray the major factors of export for Indonesian cut flower.

The measurement of bilateral exports using the gravity method provides information to improve comparative advantage mainly for export of Indonesian cut flower. Abidin et al. (2013) applied the gravity method using panel data from 1997 to 2009 to analyze the trading opportunities between Malaysia and OIC member countries. Similarly, research applied the gravity method to find out export flows of countries in the AFTA and examine Australia's trade potential (Trung Kien, 2010; Rahman, 2009). Regarding the gravity model in the most empirical studies, first, this study focuses on export of specific commodity, cut flower, between Indonesia and partner countries instead of aggregate commodity trade flows. It underlies the assumptions that the trade effects are uniform across individual commodity trade flows and might lead to the dismissal of policy determination.
The substantial commodity which has big impacts will dominate the evaluation. While cut flower instead of horticulture, has different preferential trade treatments. Moreover, the determinant factors of bilateral trade of Indonesian cut flower and the economic effects are not clearly known. Second, Indonesian cut flower has not been examined yet on the bilateral export term.

The bilateral trade flows are commonly analyzed with gravity method, the most popular and has been long proven to be a significant tool. Further, several empirical studies carried out to prove and agree to the theoretical of bilateral trade affecting factors. Trung Kien (2010) has developed the basic gravity method and found that export flows tend to increase with GDP, while distance has negative impact on export flows. In addition, Keller and Yeaple (2013) found that the physical distance can be invariance, while communication for knowledge transfer can be expensive. Thus, the result shows that the knowledge transfer of trade increases with the distance between country partners. Empirical studies related to exchange rate in specific commodities presented by Karemera et al. (2011) suggests that the trade flows in most commodities are significantly reduced due to the exchange rate uncertainty. Thus, the exchange rate volatility has 
positive impact on specific commodities trade flows. While Abidin et al. (2013) stated that inflation has negative impact since the export of a country to partner countries is decreasing if the inflation is higher. The trade openness empirically has a probable two-way causality on bilateral export to country partners. In areas of comparative disadvantage, the intermediate effect is expected to be negative as the resources become idle, while in areas of comparative advantage will carry positive impact (Falvey et al., 2012). Thus, this study investigates the export determinants of Indonesian cut flower with gravity approach.

\section{METHODS}

The gravity method is one approach to measure bilateral trade with regression analysis. The law of gravity in Physics announced by Newton has brought various empirical studies related to the gravity method of bilateral trade. The law mentions that the attraction between two figures is directly allied to their size and in reverse proportional to the distance between them.

The panel data was involved in the gravity method, meaning that the same cross-sectional unit (e.g. family or company or country) was surveyed from time to time. Thus, the panel data estimation will increase difficulty, along with the increasing regressor in the model (Gujarati and Porter, 2009). The annual data was applied with a span of 10 years, during 2008-2017. In gravity method, the 7 countries were the partners of Indonesia based on the bilateral export data between Indonesia and partner countries during 20082017. They are Malaysia, Vietnam, Singapore, China, Japan, Netherland and Saudi Arabia. Therefore, the data used in the data panel regression was 70. Gross Domestic Product (GDP), GDP per capita, and official exchange rates from the World Development Indicators (WDI) were involved in this research. Data on export of Indonesian cut flower to partner countries, import of Indonesian cut flower from all other countries, were obtained from the UN Comtrade. The data related to the distance (in kilometer) from Jakarta (capital of Indonesia) to the capital cities of partner countries were obtained from website: www.indo.com/distance.

The gravity method was employed to analyze the determinants of the competitiveness of Indonesian cut flower will apply the and the equation is as followed:

$$
\begin{aligned}
& \log \left(X_{i j t}\right)=\alpha_{0}+\beta_{1} \log \left(G D P_{i t}\right)+ \\
& \beta_{2} \log \left(G D P_{j t}\right)+\beta_{3} \log \left(G D P C A P_{i t}\right)+ \\
& \beta_{4} \log \left(G D P C A P_{j t}\right)+\beta_{5} \log \left(D I S T_{i j t}\right) \\
& +\beta_{6} \log \left(E R_{i j t}\right)+\beta_{7} \log \left(I N F_{i t}\right)_{+}
\end{aligned}
$$




$$
\begin{aligned}
& \beta_{8} \log \left(I N F_{j t}\right)+\beta_{9} \log \left(\frac{T R}{G D P}\right)_{i t}+ \\
& \beta_{10} \log \left(\frac{T R}{G D P}\right)_{J t}+\varepsilon_{i j t}
\end{aligned}
$$

Where: $\mathrm{Xijt}=$ the value of Indonesian cut flowers exports relative to the partner countries; $\mathrm{GDP}_{\mathrm{i}}=$ Gross Domestic Product of Indonesia; $\mathrm{GDP}_{\mathrm{j}}=$ Gross Domestic of partner countries; GDPCAP $_{i}=$ Gross Domestic Product per capita of Indonesia;

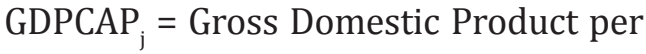
capita of partner countries; DIST $_{\mathrm{ij}}=$ distance between the capital city of Indonesia to the capital city of partner countries; $\mathrm{INF}_{\text {it }}=$ Inflation of Indonesia; $\mathrm{INF}_{\mathrm{jt}}=$ Inflation of partner countries; $\mathrm{ER}_{\mathrm{ijt}}=$ Official exchange rateof Indonesia to partner countries; TR/ $\mathrm{GDP}_{\mathrm{it}}=$ trade / GDP ratio of Indonesia; $\mathrm{TR} / \mathrm{GDP}_{\mathrm{jt}}=$ trade / GDP ratio of partner countries; $\varepsilon_{\mathrm{ijt}}=$ error; $t=$ time period; $\alpha_{0}$ $=$ constants; $\beta=$ parameter $_{1}=$ country of origin (Indonesia); ${ }_{j}=$ destination countries (partner countries). The above equation was estimated by various models, namely pooled least square (common effect), fixed effect and random effect. The appropriate model was determined by employing Chow test, Hauman test and Lagrange Multiplier test.

\section{RESULTS AND DISCUSSIONS}

\section{Data Identification and Estimation} Issues

The gravity model involved panel data analysis between Indonesia and partner countries of bilateral trade in cut flower. Indonesia has established some bilateral trades with seven countries correspondingly during the period of 2008 to 2017 to capture the productivity of Indonesian cut flower. The panel regression analysis employs balanced data due to the limited number of cross section data. First, the equation was employed in common effect/ pooled effect model. The following step was to proceed into fixed effect model. It is worth to note that the time invariant variable such as: sex, race, distant, etc. cannot be estimated by the fixed effect model (Baltagi, 2013). Several studies suggest to drop the time invariant variable, or else to apply individual dummies. Meanwhile, this research examins the gravity model in which distant variable must be presented in the regression, so dropping the variable out of the model can wipe out the main substance of gravity model. Applying individual dummies cannot be implemented since this research only has one time-invariant variable. Thus, it recommends to transform the geographical distant terminology into economic distant. Given this condition, the variables GDP per capita for Indonesia (GDAPCAPit) and GDP per capita for partner countries (GDPCAPjt) acted as the variables of size of economy. The next step, the equation was applied in random 
effect model. It required the number of independent variables which should be less than the number of cross- section variables. The seven partner countries of bilateral trade indicated that the model shall be examined in less than sevenindependent-variables. However it is also important to note that the Hausman Test should have the chi-square value in order to determine the best model whether the random effect or fixed effect model. The gravity method employed semi logarithm model for dependent variable (Xijt) and two independentvariables (Erijt and TRADE/GDPjt). The other three independent-variables were not transformed into logarithm. The transformation of both GDP per capita of Indonesia (GDPCAPit) and GDP per capita partner countries GDPCAPjt) resulting the "near singular matrix" error, and transformation for one of those variables would be biased and produce a high coeffient. Either, tranforms the distance variable into logarithm would create biased and generate a high and sharp increase in distance (Silva and Tenreyro, 2006). Taking log of the exchange rate and trade openness can stabilize the variance of the time series and t-statistics become significance.

The gravity model was analyzed by using panel data regression in common effect model/ pooled effect model and results in $5 \%$ and $1 \%$ significant level for three independent variables. However, the adjusted R-squared was relatively low. In contrast, the fixed effect model performs higher adjusted r-squared with less number of independent variables that were significant at critical value. It may be a sign of the presence of multicollinearity.

This research supposes to conduct the redundant likelihood test to select the appropriate model whether it is fixed

Table 1. Export of Indonesian Cut Flower Model $\left(\log \left(\mathrm{X}_{\mathrm{ijt}}\right)\right.$

\begin{tabular}{lrrr}
\hline Variables & Common Effect Model & Fixed Effect Model & Random Effect Model \\
\hline Constant & $22.85910^{* * *}$ & 10.74107 & $11.92850^{* * *}$ \\
GDPCAP $_{\text {it }}$ & 0.000178 & 0.000580 & $7.89 \mathrm{E}-05$ \\
GDPCAP $_{\text {jt }}$ & $-2.40 \mathrm{E}-06$ & $4.48 \mathrm{E}-05$ & $0.000105^{* *}$ \\
DISTEC $_{\mathrm{ijt}}$ & $8.79 \mathrm{E}-05^{* * *}$ & $3.09 \mathrm{E}-05$ & $-3.10 \mathrm{E}-05$ \\
$\log \left(\mathrm{Er}_{\mathrm{ijt}}\right)^{*}$ & $-0.188886^{* *}$ & $2.855053^{*}$ & 0.094275 \\
$\log \left(\mathrm{TR} / \mathrm{GDP}_{\mathrm{jt}}\right)$ & $1.415125^{* * *}$ & $-2.375310^{* * *}$ & -0.101506 \\
Adj R-Squared & 61.2280 & 85.7046 & 2.4980 \\
F-Test & 22.79265 & 38.60668 & 1.353551 \\
Chow Test & & 0.00 & \\
Hausman Test & & 0.0041 & \\
\hline
\end{tabular}

Source: Result analysis, 2019

Note : *** significance level at $1 \%$; ${ }^{* *}$ significance level at $5 \% ;{ }^{*}$ significance level at $10 \%$ 
effect model or common effect model. The outcome indicates to reject the null hypothesis due to the F-test chi-squared which is less than $5 \%$ significant level. It assumes to select the fixed effect model. Similar to the case between pooled effect and fixed effect model, the random effect model has the lowest adjusted R-squared than that in the fixed effect and pooled effect model while the independent variables, such as constant, (GDPCAPjt) show significant effect at $1 \%$ and $5 \%$ respectively. The Hausman test was employed to determine whether random effect or fixed effect model is more appropriate. In addition, the statistical result depictedthe Hausman test which proposes the fixed effect model in clarifying the export of Indonesian cut flower. The Hausman test displays the chi-square with p-value less than the critical value, then it is suggested to reject the null hypothesis. It infers that the fixed effect model is more appropriate. Hence, the fixed effect model was applied to discuss and interpret the results.

\section{The Estimation Results}

The classical assumption test indicates that heteroskedasticity and autocorrelation were presence. The solution regarding the presence of the classical assumptions issues was measured by employing the GLS model with SUR weightas shown in the following
Table 2. In Indonesia's cut flower export gravity model, the estimation confirmed that all the hypothesis sign and the data and specification were consistent with other papers and theoretical explanation. The regression estimations are as followed:

$$
\begin{aligned}
& \log \left(X_{i j t}\right)=\alpha_{0}+\beta_{1}\left(\text { GDPCAP }_{i t}\right)+ \\
& \beta_{2}\left(G D P C A P_{j t}\right)+\beta_{3}\left(\text { DISTEC }_{i j t}\right)+ \\
& \beta_{4} \log \left(E R_{i j t}\right)+\beta_{5} \log \left({\frac{T R}{G D P_{j t}}}\right)
\end{aligned}
$$

The related determinant factors to improve the export for Indonesian cut flower must rely on the empirical studies. The constant shows significance level at $5 \%$ which means that if all independent variables are zero, the minimum bilateral export is US \$18,618. The gravity method has empirically and theoretically proved the determinants that may affect the agricultural trade (Rahman, 2009). Indeed, the GDP per capita has significance impacts for exports of Indonesian cut flower. The magnitude of GDP per capita of partner countries was very small and it had 5\% significant level explaining that 1 US Dollar increase in partner country's GDP per capita, exports of Indonesia's cut flower will increase by $0.00064 \%$. Meanwhile, Indonesian GDP per capita coefficient has higher effect on the cut flower international trade, by 1 US Dollar increase in Indonesia's GDP 
per capita, exports of Indonesia's cut flower will increase by $0.039 \%$.Its existence is greatly significant at $1 \%$ level. It also means that the higher the GDP per capita of Indonesia, the higher the output of cut flower and suggested to trade. The magnitudes show that the elasticity is less than 1 which implies that the bilateral export is not sensitive to change production capacity in Indonesia or to change the GDP per capita in partner countries. The inelasticity in Indonesia may occur due to the production excess and few domestic export promotion (Karemera, et al., 2009). Several dominant importer countries of Indonesian cut flower are Japan, China and Singapore, which are also among the countries with higher average GDP per capita in account of US \$45,833; \$6,361 and \$51,407 respectively while the average GDP per capita of Indonesia during 2008-2017 is $\$ 3,271$.

The theory mentions that trade would decrease with the increase in distance between partners. However, the results show the opposite. Some empirical studies agree that the impacts of estimated distance coefficients are seemingly constant or increasing over time (Coe et al., 2007). The estimated value would increase by $0.00005 \%$ of cut flower's export as a result of $1 \mathrm{~km}$ increase in bilateral distance between
Indonesia and partner countries. The coefficient has $1 \%$ significant level. Theoretically, the coefficient of distance is associated as transportation cost and searching information cost. Hence, the increase of distance would decrease the trade flows. The facts show that the biggest importers of Indonesian cut flower in value are Japan and China, which are further than the other South East Asian Countries. For example, the average export of Indonesian cut flower to Singapore, $900 \mathrm{~km}$ away from Indonesia, is 472.3 tons and it is worth US $\$ 1,346,000$ while the average export to China which is $5,194 \mathrm{~km}$ distant from Indonesia has bigger volume in account of 776 tons and it is worth US\$ $1,814,000$. The finding is consistent with the idea that the transportation costs are in concern with the considering factors such as homogenous goods, bulky consignment and technology. Thus, it can improve the profits in cut flower international trade (Berthelon \& Freund, 2008; Carrère et al., 2013) we find that the elasticity of trade to distance increased (in absolute value. Further, the magnitude of distance is the smallest among other variables. This result is consistent with the model where fixed export costs rose gradually in distance relative to augmented trade costs. Thus, distance has little effect on the selection of export, the wide-ranging 
margin, but it has a great influence on the volume of trade (Gervais, 2015) or "openness", on economic growth is difficult to quantify because of reverse causality. In this paper, I use recent advances in gravity equation estimation to generate a geography-based instrument for openness a la Frankel and Romer (1999.

For exchange rate, the positive sign aligns to the theoretical and empirical studies, meaning that changes in the prices of partner countries' currencies in terms of U.S. Dollars correspond significantly. Appreciation of partner countries' currency (depreciation of Indonesia's currency) makes the Indonesia's product cheaper and increases trade flows (Mafizur, 2010).
It is expected that Indonesia's cut flower exports to partner countries will increase in account of $1.9039 \%$ as the depreciation of the exchange rate occurred by 1 per cent. The highest coefficient among other variables implies that the export of Indonesian cut flowers relied on its currency devaluation. Indonesia's currency experienced the lowest depreciation to Netherlands with the average exchange rate relative to Indonesia rupiah peaked at 0.000072 . Thus, the average bilateral trade flows between Indonesia and Netherlands had the biggest value to about $\$ 4,258$ million US/year, while the exchange rate of Vietnam relative to Indonesian rupiah was 1,18 with the average value of bilateral trade flows show $\$ 0.8$ million

Table 2. The Estimation results of Export of Indonesian Cut Flower (GLS Model)

\begin{tabular}{|c|c|c|c|c|}
\hline Variables & Expected sign & Coefficient & $\mathrm{p}$-value & Standard error \\
\hline $\mathrm{C}$ & & $\begin{array}{l}9.831895^{* *} \\
(4.683801)\end{array}$ & 0.0402 & 2.099127 \\
\hline GDPCAPIT & + & $\begin{array}{r}0.000386^{* * *} \\
(0.000129)\end{array}$ & 0.0041 & 2.986028 \\
\hline GDPCAPJT & + & $\begin{array}{l}6.43 \mathrm{E}-05^{* *} \\
(2.66 \mathrm{E}-05)\end{array}$ & 0.0187 & 2.418779 \\
\hline DISTEC & - & $\begin{array}{r}5.00 \mathrm{E}-05^{* * *} \\
(1.61 \mathrm{E}-05)\end{array}$ & 0.0029 & 3.106074 \\
\hline LOGERIJT & + & $\begin{array}{r}1.903896^{* * *} \\
(0.697785)\end{array}$ & 0.0084 & 2.728487 \\
\hline LOGTRGDPJT & + & $\begin{array}{r}-1.685901 * * * \\
(0.364697)\end{array}$ & 0.0000 & -4.622743 \\
\hline Adj R-Squared & & 98.42 & & \\
\hline F-Test & & 391.6589 & & \\
\hline Probability & & 0.00 & & \\
\hline
\end{tabular}

Source: Result analysis, 2019

Notes: ${ }^{* * *}$ significance level at $1 \%$; ${ }^{* *}$ significance level at $5 \% ;{ }^{*}$ significance level at $10 \%$; t-statistics in parentheses 
US/year. The positive sign corroborates with the theory and it is statistically significant at $1 \%$ critical level which mentioned that impact of exchange rate volatility is higher than GDP volatility and it is more fruitful as it occurred between developed and developing countries (Baum \& Caglayan, 2010).

Recently, the impact of trade openness is a subject of debate. According to the theory of comparative advantage, if a country trades with other countries, a country will specialize on the commodities with factor endowments and produces in a larger scale. Recently, the impact might found to be positive, negative or insignificant. The volatility of trade flows is one of the effects of trade openness in partner countries. The impact of the same trade openness is likely to be lower in a typicaldeveloped country (Levchenko et al., 2009). The coefficient for trade openness in this research was $1.686 \%$ and significant at $1 \%$ critical value. The huge coefficient number might come from the huge impacts of exporting cut flower from Indonesia (developing country) to Japan (developed country), one of the countries having the biggest export value of Indonesian cut flower. The sign is expected to be positive while this research has negative sign which means that the increasing trade volumes may be detrimental to growth percentage of GDP. One of the reasons concurrates to Huchet-Bourdon et al., (2018) emphasized that the negative impact on growth for countries which can not export better quality products and new varieties may be affected by trade openness. The export value of Indonesian cut flower has negative growth amounted to about $-0.08 \%$ / year in value and $-17 \% /$ year in quantity during 2008-2017. The difference level of trade openness may be determined by the growth effects of export. Accordingly, Indonesia must efficiently control trade openness to improve its economic growth through international trade. Further, it is in line to Falvey, et al. (2012), that the resources may become laid off since Indonesian cut flower has comparative disadvantage. The varietal development of Indonesian cut flower has grown very well, however the farmer mostly plant the varieties from abroad.

\section{CONCLUSION AND SUGGESTION}

The GLS modified model shows that the determinant factors of export for cut flower were GDP per capita of Indonesia, GDP per capita of partner countries and exchange rate which corroborated to the theoretical and empirical studies. It implies that Indonesia experienced devaluation. The coefficient of GDP per capita shows a very small number which implies that 
there is domestic production excess however the coefficient of exchange rate has the biggest impact to the trade flows.

Meanwhile, distance and trade openness had the opposite sign with the theory. It indicates that the cost arising with the increasing physical distance was not only the transportation cost. The technology had wiped out the appearance other costs such as: communication and searching information cost that may arise as the physical distance increased. Further, Indonesian cut flower has comparative disadvantage which may impact to the trade openness.

On this basis, it is required for Indonesian cut flower to promote export from the weakening of Indonesian rupiah currency and the domestic production excess. Technology improvement is required in the globalization era to suppress the communication and searching information costs. In addition, it is vital to consider the proper quality and varieties of Indonesian cut flower to be more price competitive in international market due to the trade openness.

\section{REFERENCES}

Abidin, I. S. Z., Bakar, N. A., \& Sahlan, R. (2013). The Determinants of Exports between Malaysia and the OIC Member Countries: A Gravity Model Approach. Procedia
Economics and Finance, 5(13), 12-19. https://doi.org/10.1016/ s2212-5671(13)00004-x

Baltagi, B. H. (2013). Econometric Analysis of Panel Data - Fifth Edition. In John Wiley \& Sons, 2013.

Baum, C. F., \& Caglayan, M. (2010). On the Sensitivity of the Volume and Volatility of Bilateral Trade Flows to Exchange Rate Uncertainty. Journal of International Money and Finance, 29(1), 79-93.

Berthelon, M., \& Freund, C. (2008). On The Conservation of Distance in International Trade. Journal of International Economics, 75, 310320. https://doi.org/10.1016/j. jinteco.2007.12.005

Carrère, C., de Melo, J., \& Wilson, J. (2013). The Distance Puzzle and Low-Income Countries: An Update. Journal of Economic Surveys, 27(4), 717-742. https:// doi.org/10.1111/j.1467 6419.2011.00715.x

Coe, D. T., Subramanian, A., \& Tamirisa, N. T. (2007). The missing globalization puzzle: Evidence of the declining importance of distance. IMF Staff Papers, 54(1), 34-58. https://doi.org/10.1057/ palgrave.imfsp. 9450003 
Falvey, R., Foster, N., \& Greenaway, D. (2012). Trade Liberalization, Economic Crises, and Growth. World Development, 40 (11), 2177 2193. https://doi.org/10.1016/j. worlddev.2012.03.020

Gervais, A. (2015). Trade and Growth: A Gravity Approach. Southern Economic Journal, 82(2), 453470. https://doi.org/10.2139/ ssrn.2137159

Gujarati, D. N., \& Porter, D. C. (2009). Basic Econometrics (5th ed.). In Basic Econometrics.

Huchet-Bourdon, M., Le Mouël, C., \& Vijil, M. (2018). The Relationship Between Trade Openness and Economic Growth: Some New Insights on The Openness Measurement Issue. World Economy, 26(3), 266-277. https:// doi.org/10.1111/twec.12586

Karemera, D., Managi, S., Reuben, L., \& Spann, O. (2011). The Impacts of Exchange Rate Volatility on Vegetable Trade Flows. Applied Economics, 43(13), 1607-1616. https://doi.org/10.1080/0003684 0802600137

Karemera, D., Reinstra-Munnicha, P., \& Onyeocha, J. (2009). Impacts of Free Trade Agreement on US State
Vegetable and Fruit Trade Flows. Journal of Economic Integration, 24(1), 116-134. https://doi. org/10.11130/jei.2009.24.1.116

Keller, B. W., \& Yeaple, S. R. (2013). The Gravity of Knowledge. The American Economic Review, Vol . 103 , No . 4 ( JUNE 2013 ), . 14141444 Published by : American Economic Association Stable URL : 103(4), 1414-1444.

Levchenko, A. A., Giovanni, J., \& Levchenko, A. A. (2009). Trade Openness And Volatility. The Review of Economics and Statistics, 91(3), 558-585.

Mafizur, M. (2010). The Factors Affecting Bangladesh' S Exports: Evidence From The Gravity Model Analysis. The Journal of Developing Areas, Vol. 44, No. 1 (Fall 2010), pp. 229-244 Published by : College of Business, Ten. 44(1), 229-244.

Rahman, M. M. (2009). Australia's Global Trade Potential: Evidence from the Gravity Model Analysis. Oxford Business \& Economics Conference Program, (October). Retrieved from https://eprints.usq.edu. au/5537/1/Rahman_0BEC_09_ PV.pdf

Silva, J. M. C. S., \& Tenreyro, S. (2006). The Log of Gravity. The Review 
of Economics and Statistics, Vol. 88, No. 4 (Nov., 2006), 641-658 Published by: The MIT Press Stable URL : http://www.jstor.org/ stable/40043025.88(4), 641-658.
Trung Kien, N. (2010). Gravity Model by Panel Data Approach: An Empirical Application with Implications for the ASEAN Free Trade Area. Asean Economic Bulletin, 26(3), 266-277. https://doi.org/10.1355/ae26-3c 